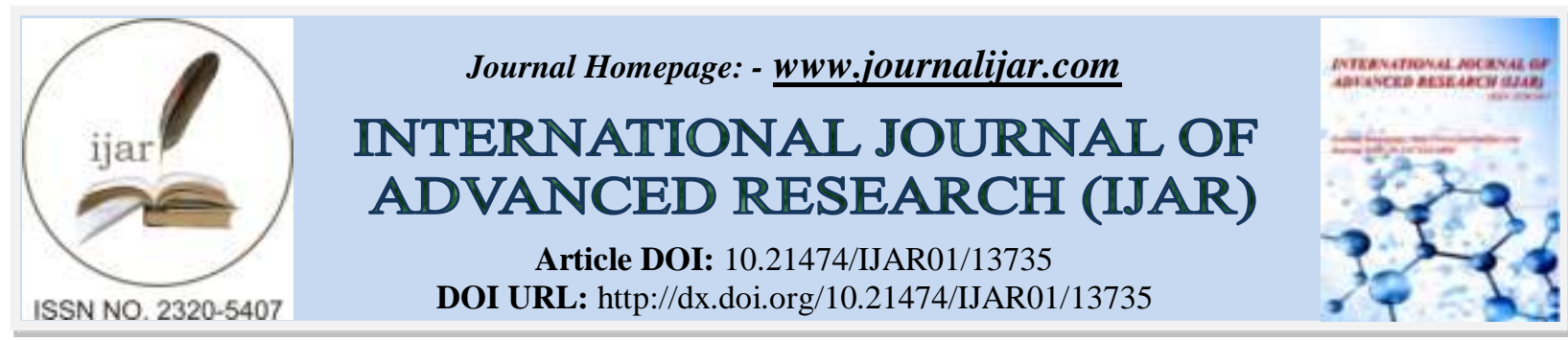

RESEARCH ARTICLE

\title{
A PRE EXPERMENTAL STUDY TO ASSESS THE EFFECTIVENESS OF A STRUCTURED TEACHING PROGRAM ON KNOWLEDGE REGARDING NECROTIZING ENTEROCOLITIS AMONGPRIMIGRAVIDA MOTHERS IN PEDIATRIC WARD OF SHRI MAHANT INDRESH HOSPITAL
}

Preeti Negi, Praveen Sharma and Archana

\section{Manuscript Info}

………………....

Manuscript History

Received: 15 September 2021

Final Accepted: 17 October 2021

Published: November 2021

\section{Abstract}

Necrotizing Enter colitis (NEC) is the devastating disease that affects mostly the intestine of premature infants. The wall of the intestine is invaded by bacteria, which cause local infection and inflammation that can ultimately destroy the wall of the wall of the bowel. NEC can develop in any new born within 2 weeks after birth. However it is most common in pre mature infants.NEC can be staged into three groups, to guide appropriate treatment based on the work of Bell et al. . In general, stage I and II are managed medically whereas stage III is managed surgically.Trigger factors (i.e. prenatal hypoxia, mild infection or formula feeding) cause focal mild intestinal mucosal injury. In the presence of proliferation of commensal bacteria, local breakdown of mucosal barrier may cause entry of bacterial products (e.g. lipo polysaccharides, platelet-activating factor).

Aim: The aim of the study was to assess the knowledge regarding necrotizing enterocolitis

Method And Materials: A pre experimental study used to accomplish the objectives. Study was undertaken on 60 primigravida mothers in pediatric ward in Shri Mahant Indresh Hospital Dehradun by using convenient sampling technique. Participants were selected on the basis of inclusion and exclusion criteria Structure knowledge questionnaire, observation, pre test, post test were used to asses knowledge and practice.

Conceptual Framework: Conceptual framework acts as a building blocks for study. In this study, modified General system theory was used as the investigator aim as to assess the pre test knowledge and post test knowledge regarding necrotizing enterocolitis.

Result:There is highest percentage of primigravida mothers according to their Table and Graph shows the Age interval wise distribution of the study subjects. It is illustrated from table that the majority of the participant 26(43.3\%) in were 26-30 year compare to another age interval in our study. The Area of Residence wise distribution of the study subjects. It is illustrated from table that the majority of the participant 26(43.3\%) in were Rural compare to another Area of Residence in our study. The Monthly Income of Family wise distribution of the study subjects. It is illustrated from table that the majority of the participant $21(35.0 \%)$ in were $>40000$ compare to 
another Monthly Income of Family in our study. The Occupation wise distribution of the study subjects. It is illustrated from table that the majority of the participant $25(41.7 \%)$ in were Gov employee compare to another Occupation in our study. The First Language wise distribution of the study subjects. It is illustrated from table that the majority of the participant $49(81.7 \%)$ in were the Religion wise distribution of the study subjects. It is illustrated from table that the majority of the participant $49(81.7 \%)$ in were Hindu compare to another Religion in our study. the Education wise distribution of the study subjects. It is illustrated from table that the majority of the participant 23(38.3\%) in were High School compare to another Education in our study. the Type of Family wise distribution of the study subjects. It is illustrated from table that the majority of the participant $40(66.7 \%)$ in were Nuclear compare to another Type of Family in our study. Table and Graph shows the Mode of Delivery wise distribution of the study subjects. It is illustrated from table that the majority of the participant $37(61.7 \%)$ in were Normal compare to another Mode Of Delivery in our study. the Pre Test Level wise distribution of the study subjects. It is illustrated from table that the majority of the participant 55(91.7\%) in were Inadequate Knowledge compare to another Pre Test Level in our study. There is significant difference between the pre-test and post test score of knowledge questionnaires was demonstrated by using paired' test and computed between pre test and post test knowledge score. The value of paired' test of knowledge score is 15.20 with the table value of 2.02 at 0.05 level of significance was found to be highly significant relationship between pre test and post test scores. So, in this study it was found that Structural teaching program was effective in improving the knowledge level among the primigravida mothers regarding necrotizing enter colitis. The study proved that there was no association found between knowledge score and selected demographic variables of age of primigravida mothers, Area of residence, Monthly income of family, Occupation, First language, Religion, Education, Socio economic status, Type of family, Mode of delivery at 0.05 level of significance. Hence the research hypothesis $\mathrm{H} 2$ is not accepted. The study proved that there is no significant association between knowledge scores with their selected demographic variables.

Discussion:Based on the objectives of the study, a knowledge questionnaire was used to assess the effectiveness of structured teaching program. It was considered to be appropriate instrument.

Conclusion: Study revealed that in response to knowledge questionnaires in Pre test of subject $0 \%$ have adequate knowledge and that was increased to $55 \%$. Moderate knowledge score in pre test was $5 \%$ that was reduced to $40 \%$. Inadequate knowledge score in pre test was $8.3 \%$ that was to $0 \%$ in post test. This indicate that Structural teaching program are effective in improving knowledge.

Copy Right, IJAR, 2021,. All rights reserved.

\section{Introduction:-}

Necrotizing enter colitis (NEC) is a devastating disease of premature infants, with a mortality rate of $10-50 \%$. It is uncommon in term infants and in premature infants who have not yet been fed. Most commonly NEC develops suddenly in a preterm infant who was otherwise well, with initial symptoms of abdominal distention, bilious or bloody emesis or gastric aspirates, hematochezia, and pneumastosis intestinalis, and sometimes progresses quickly to include bowel perforation, acidosis, shock, and death. Trigger factors (i.e. prenatal hypoxia, mild infection or formula feeding) cause focal mild intestinal mucosal injury. In the presence of proliferation of commensal bacteria, 
local breakdown of mucosal barrier may cause entry of bacterial products (e.g. lipo polysaccharides, plateletactivating factor

\section{Objectives:-}

1-To assess the knowledge regarding necrotizing enter colitis among primi gravida mothers.

2-To assess the effectiveness of structural teaching program regarding necrotizing enter colitis.

3-To find out the association between the pretest knowledge of necrotizing enter colitis among primigravida mothers with selected demographic variables.

4-To find out the association between the pretest knowledge of primigravida knowledge regarding necrotizing enter colitis with selected demographic variables.

\section{Review Of Literature:-}

1-Review of literature related to prevalence of necrotizing enter colitis

2-Review of literature related to knowledge regarding necrotizing entero colitis

3-Review of literature related to prevention and management of necrotizing enter colitis.

4. Review of literature related to prevalence of pre-term babies

\section{Research Methodology:-}

Research Approach:

Quantitative research

Research Design:

Descriptive research design

Research variables:

Knowledge

\section{Demographic variables:}

Extraneous variables are the factors that are not the part of the study but may affect the measurement of study variables. In this study, demographic variables refer to age of primigravida mothers, education of mothers, source of information, socio economic status, living status, previous history of Necrotizing enterocolitis.

\section{Setting of the study:}

Shri Mahant Indresh hospital , Dehradun

\section{Population -}

Primigravida mothers

\section{Target population -}

Primigravida mothers in pediatric mothers

\section{Accessible population -}

Primigravida mothers in pediatric ward

\section{Sample size :}

60

\section{Tool}

Section A : Demographic data

Section B : Structured knowledge questionnaire for knowledge

Section C : Demographic data 


\section{Pilot Study}

The tool was administered on 6 samples and the reliability of tool was found by using Karl Pearson Co-relation coefficient formula. The reliability of the tool was found to be $(r=0.73)$ that is a reliable. Hence the tool is found to be highly reliable.

The pilot study was conducted in Pediatric ward at Shri Mahant Indresh Hopital in which 6 primigravida mothers with convenient sampling. The tool was used for pilot study to test the feasibility and practicability.

\section{Data Collection}

It involves estimating the value of unknown parameters of the population and testing of hypothesis for drawing inferences. It was decided to analysis the data by both descriptive and inferential statistics on the basis of objective and hypothesis of the study. Master data sheet will be prepared by investigator to analyse the data. The data will be analyze in the term of descriptive (mean, percentage, SD) and inferential statistics ("t" test and chi square).

The period of data collection was extended from. The purpose and nature of the study was explain to the primigravida mothers and their consent was obtained. The structured questionnaire will be prepared and administered to assess the pre-test level of knowledge of primigravida mothers regarding necrotizing enterocolitis

\section{Results:-}

Table:- Frequency and percentage distribution of demographic variables of nurses.

\begin{tabular}{|c|c|c|c|}
\hline s.no. & Demographic variables & $\begin{array}{c}\text { Frequency (f) } \\
\text { n-60 }\end{array}$ & Percentage (\%) \\
\hline 1. & $\begin{array}{ll}\text { Age in years: } \\
-\quad 20-25 \\
-\quad 26-30 \\
-\quad>30 \\
\end{array}$ & $\begin{array}{l}22 \\
26 \\
12 \\
\end{array}$ & $\begin{array}{l}36.7 \% \\
43.3 \% \\
20.0 \% \\
\end{array}$ \\
\hline 2. & $\begin{array}{cl}\text { Area of residence } \\
\text { - } & \text { Rural } \\
\text { - } & \text { Semi-Urban } \\
\text { - } & \text { Urban } \\
\end{array}$ & $\begin{array}{l}26 \\
21 \\
13\end{array}$ & $\begin{array}{l}43.3 \% \\
35.0 \% \\
21.7 \%\end{array}$ \\
\hline 3. & $\begin{array}{c}\text { Monthly income of family } \\
\text { - } \quad 20,000-30,000 \\
\text { - } \quad 30,000-40,000 \\
\text { - }>40,000\end{array}$ & 19 & $\begin{array}{l}31.7 \% \\
33.3 \% \\
35.0 \%\end{array}$ \\
\hline 4. & $\begin{array}{cl}\text { Occupation } \\
\text { - } & \text { Work part } \\
\text { - } & \text { Private Job } \\
\text { - } & \text { Govt. Job }\end{array}$ & $\begin{array}{l}20 \\
15 \\
25\end{array}$ & $\begin{array}{l}33.3 \% \\
25.0 \% \\
41.7 \%\end{array}$ \\
\hline 5. & $\begin{array}{c}\text { First language } \\
-\quad \text { English } \\
\text { - Hindi }\end{array}$ & 11 & $\begin{array}{r}18.3 \% \\
81.7 \%\end{array}$ \\
\hline 6. & \begin{tabular}{ll}
\multicolumn{2}{l}{ Religion } \\
- Hindu \\
- $\quad$ Muslim \\
- Christian
\end{tabular} & $\begin{array}{r}49 \\
9 \\
2\end{array}$ & $\begin{array}{r}81.75 \\
15.0 \% \\
3.3 \%\end{array}$ \\
\hline 7. & \begin{tabular}{ll}
\multicolumn{2}{l}{ Education } \\
$\qquad \quad$ High-School \\
- Inter-mediate \\
- $\quad$ Graduate
\end{tabular} & $\begin{array}{l}23 \\
22 \\
15\end{array}$ & $\begin{array}{l}38.3 \% \\
36.7 \% \\
25.0 \%\end{array}$ \\
\hline 8. & $\begin{array}{l}\text { Socio economic status } \\
\qquad \quad \text { Upper and middle clas }\end{array}$ & 23 & $38.3 \%$ \\
\hline
\end{tabular}




\begin{tabular}{|c|c|c|c|}
\hline & $\begin{array}{ll}\text { - } & \text { Lower middle } \\
\text { - } & \text { Lower class }\end{array}$ & $\begin{array}{l}22 \\
15\end{array}$ & $\begin{array}{r}36.6 \% \\
25 \%\end{array}$ \\
\hline 9. & $\begin{array}{l}\text { Type of family } \\
\qquad \quad \text { Nuclear family } \\
\text { - Joint family }\end{array}$ & $\begin{array}{l}40 \\
20\end{array}$ & $\begin{array}{l}66.6 \% \\
33.3 \%\end{array}$ \\
\hline 10. & $\begin{array}{l}\text { Mode of delivery } \\
\text { - Normal delivery } \\
\text { - Cessarian Delivery }\end{array}$ & $\begin{array}{l}37 \quad 23 \\
\end{array}$ & $\begin{array}{l}61.75 \% \\
38.3 \%\end{array}$ \\
\hline
\end{tabular}

Section C:

Effectiveness of intervention in the terms of increase the knowledge level.

Table 2:- Frequency and percentage distribution of the pre and post test score test . N=60

\begin{tabular}{|l|l|l|l|l|l|}
\hline $\begin{array}{l}\text { Level } \\
\text { knowledge }\end{array}$ & $\begin{array}{l}\text { Score range } \\
\text { Frequency } \\
\text { N=60 }\end{array}$ & Percentage & $\begin{array}{l}\text { Post test } \\
\text { Frequency } \\
\text { N=60 }\end{array}$ & Percentage \\
\hline $\begin{array}{l}\text { Inadequate } \\
\text { knowledge }\end{array}$ & $<50 \%$ & 55 & $91.7 \%$ & 4 & $6.7 \%$ \\
\hline $\begin{array}{l}\text { Moderate } \\
\text { knowledge }\end{array}$ & $51-75 \%$ & 5 & $8.3 \%$ & 4 & $6.7 \%$ \\
\hline $\begin{array}{l}\text { Adequate } \\
\text { knowledge }\end{array}$ & $76-100 \%$ & 0 & 0 & 52 & $86.7 \%$ \\
\hline
\end{tabular}

Section D:

Comparison Of Pre Test And Post Test Knowledge Score Along With Findings Of Effectiveness Of Information Structural Teaching Program On Knowledge Of Primigravida Mothers.

\begin{tabular}{|l|c|c|c|l|l|l|}
\hline $\begin{array}{l}\text { Knowledge } \\
\text { score value }\end{array}$ & Mean & SD & Df & $\begin{array}{l}\text { Calculated “t” } \\
\text { value }\end{array}$ & Table value & $\begin{array}{l}\text { Level } \\
\text { significance }\end{array}$ \\
\hline Pre test & 2.67 & 8.15 & 59 & 5.58 & 2.02 & Significant \\
\hline Post test & 2.56 & 18.72 & & & & \\
\hline
\end{tabular}

\section{Discussion:-}

A report of finding is never sufficient to convey their significance. The meaning that research to the result play a rightful and important role in the report. The discussion selection is devoted to a thoughtful and insightful analysis of the finding, leading to discussion of their clinical and theoretical utility. 
This chapter deals with the discussion in accordance with the objectives of the study and hypothesis. The statement of the problem was " A pre experimental study to assess the effectiveness of a Structured teaching program on knowledge regarding necrotizing enterocolitis among primigravida mothers in Pediatric unit of Shri Mahant indresh Hospital, Dehradun.

Structural teaching program was assessed by paired "t" test. Chi-square was used to find association between the pre test with their selected demographic variables such as age, mode of delivery, type of family, occupation , educational status, area of residence, monthly income of family, First language, Religion, Socio economic status. 